\title{
Alkaloids derived from flowers of Senna spectabilis, (-)-cassine and $(-)$-spectaline, have antiproliferative activity on HepG2 cells for inducing cell cycle arrest in G1/S transition through ERK inactivation and downregulation of cyclin D1 expression
}

\author{
Rodrigo Machado Pereira ${ }^{a}$, Guilherme Álvaro Ferreira-Silva ${ }^{a}$, Marcos Pivatto ${ }^{b}$, Luciana de Ávila Santos ${ }^{c}$, \\ Vanderlan da Silva Bolzani ${ }^{\mathrm{c}}$, Daniela Aparecida Chagas de Paula ${ }^{\mathrm{d}}$, Jaqueline Carvalho de Oliveira ${ }^{\mathrm{e}}$, \\ Cláudio Viegas Júnior ${ }^{\mathrm{f}}$, Marisa Ionta ${ }^{\mathrm{a}, *}$ \\ a Institute of Biomedical Sciences, Federal University of Alfenas, Rua Gabriel Monteiro da Silva, 700, zip code 37130-000 Alfenas, MG, Brazil \\ ${ }^{\mathrm{b}}$ Nucleus of Research in Natural Products (NuPPeN), Institute of Chemistry, Federal 'University of Uberlândia, Avenida João Naves de Ávila, 2121, zip code 38408-144 Uberlândia, MG, Brazil \\ ${ }^{c}$ Institute of Chemistry, State University of São Paulo, Rua Francisco Degni s/n, zip code 14801-970 Araraquara, SP, Brazil

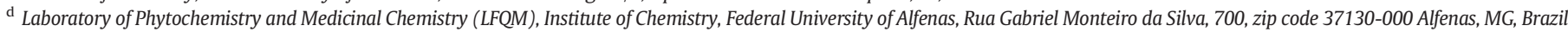 \\ e Institute of Natural Science, Federal University of Alfenas, Rua Gabriel Monteiro da Silva, 700, zip code 37130-000 Alfenas, MG, Brazil \\ ${ }^{\mathrm{f}}$ Laboratory of Research on Medicinal Chemistry (PeQuiM), Institute of Chemistry, Federal University of Alfenas, Av. Jovino Fernandes Sales, 2600, zip code 37130-000 Alfenas, MG, Brazil
}

\section{A R T I C L E I N F O}

\section{Article history:}

Received 4 September 2015

Received in revised form 17 November 2015

Accepted 22 November 2015

Available online 23 November 2015

\section{Keywords:}

Hepatocellular carcinoma

Cell cycle arrest

$(-)$-Cassine

$(-)$-Spectaline

Piperidine alkaloids

Senna spectabilis

\begin{abstract}
A B S T R A C T
Cancer is one of the most critical problems of public health in the world and one of the main challenges for medicine in this century. Unfortunately, most patients are diagnosed at advanced stage, when the treatment options are palliative. Consequently, the search for novel therapeutic options is imperative. In the context, the plants represent an important source for discovering of novel compounds with pharmacological potential including antineoplastic agents. Herein, we aimed to investigate in vitro antiproliferative and cytotoxic potentials of an alkaloid mixture derived from Senna spectabilis, (-)-cassine (1) and (-)-spectaline (2). These alkaloids reduced cell viability in a concentration-dependent manner of six tumor cell lines. From initial screening, HepG2 cells were selected for further investigations. We show that alkaloids $\mathbf{1} / \mathbf{2}$ have an important antiproliferative activity on HepG2 cells due to their ability in inducing cell cycle arrest in G1/S transition. This effect was associated to ERK inactivation and down-regulation of cyclin D1 expression. In addition, we evidenced a disruption of the microfilaments and microtubules in a consequence of the treatment. Taken together, the data showed by the first time that alkaloids $\mathbf{1} / \mathbf{2}$ strongly inhibit cell proliferation of hepatocellular carcinoma cells. Therefore, they represent promise antitumor compounds against liver cancer and should be considered for further anticancer in vivo studies.
\end{abstract}

(c) 2015 Elsevier Ltd. All rights reserved.

\section{Introduction}

Cancer is one of the most critical problems of public health in the world and one of the main challenges for medicine in this century. According to GLOBOCAN 2012, an estimated million new cancer cases and 8.2 million deaths occurred in 2012 worldwide. Incidence rates for all cancers combined in economically developed countries are nearly twice as high as in economically developing countries in both males and females (Torre et al., 2012).

Hepatocellular carcinoma (HCC) is the second most common cause of death from cancer worldwide (Bum et al., 2010) and, unfortunately, many cases are still diagnosed at advanced stages when treatment

\footnotetext{
* Corresponding author.

E-mail address: marisaionta@gmail.com (M. Ionta).
}

options are only palliative (Lorenzi, 1998). Excessive alcohol consumption and Hepatitis B and C virus are important risk factors for HCC (Nsonde-Ntandou et al., 2005; Pivatto et al., 2005). Actually, therapeutic approaches for HCC at advanced stage include the use of multikinase inhibitors (Bruix et al., 2012); however, clinical trials have evidenced just a modest survival benefit. Accordingly, it is relevant to identify new compounds with promise antitumor activity against HCC.

Plants represent a promise source for discovery of new prototypes with pharmacological potential, because contain a wide spectrum of bioactive secondary metabolites (Viegas et al., 2006). Senna is one of the biggest genus of the Fabaceae family, comprising about 600 species, many of them widely used in Traditional Medicine. Senna spectabilis (sin. Cassia excelsa var. Acutifolia, Cassia carnaval, Cassia spectabilis) is an endemic tree of South America and Africa, very common in Brazil and Colombia (Bolzani et al., 1995; Jothy et al., 2012; Silva et al., 2010; 
Veerachari and Bopaiah, 2011). Senna species have a diverse chemical profile, accumulating secondary metabolites with a great structural diversity including flavonoids, tannins, saponins, carbohydrates, antraquinones, stilbenoids, xanthines, triterpenes, steroidal compounds and alkaloids (Agarkar and Jadge, 1999; Akah et al., 1998; Ayo et al., 2007; Bhakta et al., 1999; Ibrahim and Osman, 1995; Samy et al., 1998). Many biological properties of $S$. spectabilis have been reported such as anticonvulsive, sedative, antimalarial, antimicrobial and cytotoxic activities (Jafri et al., 1999; Jain et al., 1997; Mascolo et al., 1998; Samy and Ignacimuthu, 2000; Tona et al., 1999). Recently, our group reported leishmanicidal potential of the flowers extract of S. spectabilis which was associated to the presence large amounts of the alkaloids $(-)$-cassine (1)/(-)-spectaline (2) (Fig. 1) (Viegas et al., 2006). In another work, Bolzani and co-workers (Bolzani et al., 1995) have reported the selective cytotoxic activity of $(-)$-spectaline $(\mathbf{2})$ against mutant yeasts of Saccharomyces cerevisiae, which is a screening method commonly used for bioprospection of potential antitumor natural products. Nevertheless, the antitumor potential of these alkaloids has been poorly investigated up to date. In a previous work, we have described the isolation of a mixture (6:4) of $(-)$-cassine $(\mathbf{1})$ and $(-)$-spectaline (2), which are the major alkaloidal constituents of the leaves, flowers and fruit extracts of $S$. spectabilis. Following up with our previous studies, and considering the selective cytotoxicity potential of these alkaloids for S. cerevisiae, here we aimed to deepen investigate their effect on tumor cell lines.

\section{Materials and methods}

\subsection{Plant material, preparation of the extracts and isolation}

The flowers of $S$. spectabilis were collected in the region of Araraquara-SP (Brazil), during January 2013. The voucher specimen is deposited in the Herbarium of the Botanical Garden of São Paulo under the registry SP 370.917.

The plant material was treated with some adaptations of previously reported methods (Pivatto et al., 2005; Viegas et al., 2004, 2013). The fresh flowers of $S$. spectabilis were dried in a stove at $40{ }^{\circ} \mathrm{C}$ for $24 \mathrm{~h}$, followed by grinding and maceration in EtOH for 6 days, filtering and concentrating the extract and adding more $3 \mathrm{~L}$ of solvent to the residual plant material by each 2 days. At the end, all maceration extracts were combined and concentrated to furnish $104 \mathrm{~g}$ of the ethanolic extract, which was redissolved in $\mathrm{MeOH} / \mathrm{H}_{2} \mathrm{O}$ (8:2) and partitioned successively with hexanes and $\mathrm{CH}_{2} \mathrm{Cl}_{2}$. The $\mathrm{CH}_{2} \mathrm{Cl}_{2}$ fraction is known [5-7] to contain the highest concentration of alkaloidal metabolites, especially $\mathbf{1}$ and $\mathbf{2}$, and was concentrated to furnish $39 \mathrm{~g}$ of material. This crude fraction was redissolved in $100 \mathrm{~mL}$ of $\mathrm{CH}_{2} \mathrm{Cl}_{2}$ and extracted with $40 \%$ aqueous $\mathrm{HCl}(3 \times 50 \mathrm{~mL})$; the combined aqueous fractions were adjusted to pH 9 using concentrated $\mathrm{NH}_{4} \mathrm{OH}$ and the resultant basic aqueous solution was exhaustively extracted with $\mathrm{CH}_{2} \mathrm{Cl}_{2}$, dried over $\mathrm{MgSO}_{4}$ and concentrated, providing $9 \mathrm{~g}$ of a crude alkaloidal fraction. This alkaloidal portion was then purified by column chromatography (CC, neutral $\mathrm{Al}_{2} \mathrm{O}_{3}$ ), eluted with $\mathrm{EtOH} / \mathrm{CH}_{2} \mathrm{Cl}_{2} /$ hexanes (1:7:2), providing a mixture of 1 and $\mathbf{2}$ (4.82 g), along with a complex mixture of other more polar alkaloidal metabolites. It is known that almost all alkaloids from the flowers S. spectabilis occur in mixtures of two homolog-derivatives, differing only by two methylene units in side chain (Pivatto et al., 2005). So, the mixtures of such homologs are very difficult to separate and we decided to evaluate them as a 57:43 mixture of $\mathbf{1}$ and $\mathbf{2}$, respectively (LC-MS).

\subsection{Cell lines and treatment schedule}

Cell lines derived from human cancer were used in this study: A549 (lung carcinoma), MCF-7 and Hs578T (breast carcinoma), HepG2 (hepatocellular carcinoma), U138MG and U251MG (glioblastoma). In addition, normal fibroblast (CCD-1059Sk), derived from skin, was used to determine selectivity index. The cell cultures were maintained in DMEM (Dulbecco's Modified Eagle's Medium, Sigma, CA, USA) supplemented with $10 \%$ fetal bovine serum (Vitrocell, Campinas, Brazil). Cells were grown in a $37{ }^{\circ} \mathrm{C}$ humidified incubator containing $5 \% \mathrm{CO}_{2}$.

Alkaloid mixture containing (-)-cassine $(\mathbf{1}) /(-)$-spectaline (2) was solubilized in DMSO and stock solution at $20 \mathrm{mg} / \mathrm{mL}$ was stored at $-20{ }^{\circ} \mathrm{C}$ until use. After attachment $(24 \mathrm{~h})$, the cells were treated for $24 \mathrm{~h}, 48 \mathrm{~h}$ or $72 \mathrm{~h}$.

\subsection{Cell viability analysis}

Cell viability was measured by MTS (dimethylthiazol carboxymethoxyphenyl sulfophenyl tetrazolium) assay using CellTiter 96® Aqueous Non-Radiative Cell Proliferation assay (Promega) according to manufacturer's instructions. For this propose, $2 \times 10^{4}$ cells were seeded into 96-well plate. Alkaloid mixture was used in different concentrations $(5-80 \mu \mathrm{g} / \mathrm{mL})$ for $48 \mathrm{~h}$. Formazan, the reduced form of tetrazolium, absorbs light at $490 \mathrm{~nm}$ and viable cells rate is directly proportional to the amount of produced formazan by dehydrogenase enzymes. Experiments were conducted in triplicate wells. Data are presented as the mean \pm standard deviation (SD) of 4 independent experiments. The $\mathrm{IC}_{50}$ value was determined from non-linear regression using GraphPad Prism ${ }^{\circledR}$ (GraphPad Software, Inc., San Diego, CA, USA). Doxorubicin was used as a positive control at $0.125-1 \mu \mathrm{g} / \mathrm{mL}$ concentration range.

\subsection{Trypan blue exclusion test}

Cells were seeded onto $35 \mathrm{~mm}$ plates at $2 \times 10^{5}$ density. Treatment was performed at $20-80 \mu \mathrm{g} / \mathrm{mL}$ concentration range. Cells were harvested with trypsin/EDTA and trypan blue solution (0.4\%) was added to cellular suspension (1:1). Subsequently, cells were counted using a hemocytometer chamber and a light microscope. Thus, non-viable cells (blue stained) and viable cells (unstained) were quantified from 3 independent experiments. The results are presented as means \pm standard deviations (SD).

\subsection{Cell cycle analysis}

Cells were treated with the alkaloids mixture for $24 \mathrm{~h}$ at $5-40 \mu \mathrm{g} / \mathrm{mL}$ for cell cycle analysis. The cells were fixed with $75 \%$ ethanol at $4{ }^{\circ} \mathrm{C}$ overnight, rinsed twice with cold phosphate-buffered saline (PBS). Following, cells were homogenized in dye solution [PBS containing $30 \mu \mathrm{g} / \mathrm{mL}$ propidium iodide (PI) and $3 \mathrm{mg} / \mathrm{mL}$ RNAase]. DNA was quantified $1 \mathrm{~h}$ after staining. The analysis was performed by flow cytometry (Guava easyCyte 8HT, Hayward, CA, USA) and cell population frequencies (G1, $\mathrm{S}$ and $\mathrm{G} 2 / \mathrm{M}$ ) were determined using FlowJo software. Results are presented as means \pm standard deviations (SD) of 3 independent experiments. Doxorubicin was used as a positive control at $0.125-1 \mu \mathrm{g} / \mathrm{mL}$ concentration range.
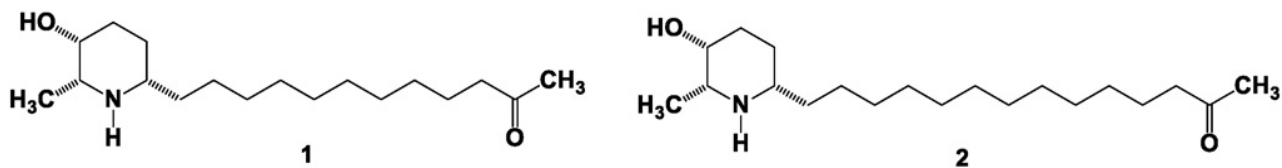

Fig. 1. Chemical structures of (-)-cassine (1) and (-)-spectaline (2), the two major alkaloidal constituents in S. spectabilis. 


\subsection{Clonogenic formation assay}

Clonogenic assay was performed according to Franken et al. (2006). Briefly, $1 \times 10^{4}$ cells were seeded in $35 \mathrm{~mm}$ plates. Cells were treated for $24 \mathrm{~h}$ and recovery in drug-free medium subsequently for 15 days. Following, the colonies were fixed and stained with Cristal Violet. Only colonies with $>50$ cells were counted by direct visual inspection with a stereo microscope at $20 \times$ magnification. Assays were performed in triplicate and the data presented as mean \pm SD of 3 independent experiments.

\subsection{Cytoskeleton elements analysis}

Cells were seeded on coverslips and fixed with 3.7\% formaldehyde for $30 \mathrm{~min}$. For $\alpha$-tubulin immunolabeling, cells were permeabilized with Triton X-100 (0.5\%) for 10 min. After blocking with $1 \%$ BSA, primary antibody (1:100, Sigma Aldrich) was incubated overnight. On next day, secondary anti-mouse IgG-TRITC antibody (1:100, Sigma Aldrich) was added to sample and incubated for $2 \mathrm{~h}$. Following, phalloidin-FITC (Sigma Aldrich) incubation (1 h) was performed for actin labeling. Nuclei were stained with DAPI and coverslips were mounted on microscope slides using Vecta-Shield (Vector Laboratories). All washes were done with phosphate-buffered saline (PBS). Analyses were performed using a fluorescence microscope (Nikon).

\subsection{Mitotic index}

Mitotic cells were counted from fluorescent cytological preparations containing DAPI stained nuclei; 1000 cells for sample were counted. Data are shown as mean \pm SD of 3 independent experiments.

\subsection{Immunoblot}

Cells were homogenized in RIPA buffer ( $150 \mathrm{mM} \mathrm{NaCl}, 1.0 \%$ Nonidet P-40, 0.5\% deoxycholate, $0.1 \%$ SDS and $50 \mathrm{mM}$ Tris $\mathrm{pH} 8.0$ ) containing both protease and phosphatase inhibitors (Sigma). Lysates were centrifuged $(10,000 \times \mathrm{g})$ for $10 \mathrm{~min}$ at $4{ }^{\circ} \mathrm{C}$. Supernatants were recovered, total proteins were quantified (BCA kit, Pierce Biotechnology Inc., Rockford, IL, USA) and resuspended in Laemmli sample buffer containing 62.5 mM Tris-HCl pH 6.8, 2\% SDS, 10\% glycerol, 5\% 2-mercaptoethanol and $0.001 \%$ bromophenol blue. An aliquot of $50 \mu \mathrm{g}$ protein was separated by SDS-PAGE (12\%) and transferred (100 V, $250 \mathrm{~mA}$ for $2 \mathrm{~h}$ ) onto a PVDF membrane (Amersham Bioscience), which was blocked by incubation for $1 \mathrm{~h}$ at $4{ }^{\circ} \mathrm{C}$ with blocking solution [ $5 \%$ non-fat milk in Tris-buffered saline (TBS) $+0.1 \%(v / v)$ Tween-20] to prevent nonspecific protein binding. Membrane was probed with primary antibodies: (Tyr 204) phosphorylated ERK antibody (Santa-Cruz - 1:50), ERK 1 (Santa-Cruz 1:1000), phospho-histone H3 (Santa-Cruz - 1: 200) and $\alpha$-tubulin (Sigma - 1:1000) overnight at $4{ }^{\circ} \mathrm{C}$. After washing with TBS-tween $(0.1 \%)$, the membrane was incubated with secondary antibody (antirabbit peroxidase conjugated) for $2 \mathrm{~h}$ at room temperature. Immunoreactive bands were visualized with the ECL Western blotting detection Kit (Amersham Pharmacia). Reprobing protocol was used for detecting immunoreactive bands for different antibodies. Results were obtained from 3 independent experiments and densitometric analysis was performed using NIH ImageJ.

\subsection{RNA extraction, $C D N A$ synthesis and quantitative real time $P C R$ ( $q R T-P C R)$}

Total cellular RNA was extracted using TRIzol Reagent (Invitrogen, Carlsbad, CA, USA). The RNA was stored in DEPC-treated water at $-80{ }^{\circ} \mathrm{C}$ and, before use; the quantity and quality of samples were evaluated by ND-1000 NanoDrop spectrophotometer (NanoDrop Technologies). $500 \mathrm{ng}$ of total RNA was retro-transcribed with random primers and SuperScript III reverse transcription kit (Applied Biosystems,
Foster City, CA), and qRT-PCR was then performed using SybrGreen PCR Master Mix (Applied Biosystems, Foster City, CA).

Gene was measured using the ABI 7500 Real Time PCR System (PE Applied Biosystems). The relative expression was calculated using the $2^{-\Delta \Delta C T}$ method (Livak and Schmittgen, 2001) with GAPDH as internal control. The expression levels in negative non-treated controls were used as calibrator.

Primers sequences used for expression analysis were: GAPDH (AGAT CCCTCCAAAATCAAGTGG/GGCAGAGATGATGACCCTTTT) and cyclin D1 (CCTCCTCCTCGCACTTCTGT/CCGTCCATGCGGAAGATC). Real time PCR was performed in triplicate and a standard deviation (SD) of $<0.5$ was accepted. A blank control was run in parallel to determine the absence of contamination. The data are presented as mean \pm SD from 3 independent experiments.

\subsection{Statistical analysis}

For qRT-PCR data, Student's test was used to analyze significant differences. $\mathrm{p}<0.05$ was considered as statistically significant. Results obtained of other experimental approaches were tested for significance using one-way analysis of variance (ANOVA) followed Tukey's posttest. The values were expressed as mean \pm SD.

\section{Results}

The mixture of $(-)$-cassine $(\mathbf{1})$ and $(-)$-spectaline $(\mathbf{2})$ reduced cell viability in a concentration-depend manner of six cancer cell lines (Fig. 2A). From initial screening, HepG2 cells were selected as a study model for further investigations. $\mathrm{IC}_{50}$ value (concentration that inhibits $50 \%$ of the growth) found for HepG2 cell line was $26.45 \pm 1.73 \mu \mathrm{g} / \mathrm{mL}$, while in normal fibroblast cells the $\mathrm{IC}_{50}$ value was $55.62 \pm 1.69 \mu \mathrm{g} / \mathrm{mL}$. We verified that selectivity index of the alkaloids was higher than doxorubicin, a powerful chemotherapeutic agent (Table 1).

Strong cytotoxic activity of alkaloids $\mathbf{1} / \mathbf{2}$ was observed only when concentration upward to $\mathrm{IC}_{50}$ value was used (Fig. 2B) for $48 \mathrm{~h}$. These data corroborated those previously obtained by MTS. In addition, we also observed drastic alteration in cell morphology when high concentrations were used (Fig. 2C). Normally HepG2 cells exhibit polygonal morphology and grow arranged in clusters. Drastic morphological alteration was observed in cells treated for $48 \mathrm{~h}$ with $40 \mu \mathrm{g} / \mathrm{mL}$ of alkaloids mixture once cells became rounded and less adhered to substratum (Fig. 2C).

Following, we evaluated the pattern of distribution of cytoskeleton elements (actin filaments and microtubules) aiming to collect more information concerning alkaloids effects on HepG2 cell morphology. We demonstrated that cytoskeleton was drastically altered when compounds $\mathbf{1} / \mathbf{2}$ were used in concentrations upward at $20 \mu \mathrm{g} / \mathrm{mL}$ (Fig. 2C). The data reinforce the previous results concerning alkaloids cytotoxicity.

In the next step, we investigated the influence of compounds $\mathbf{1 / 2}$ on proliferative behavior of HepG 2 cells. We performed the counting cells 24,48 or $72 \mathrm{~h}$ in presence or absence of alkaloids. Alkaloid mixture at $20 \mu \mathrm{g} / \mathrm{mL}$ was effective in inhibiting cell proliferation from $24 \mathrm{~h}$ (Fig. 3A). Thus, we determined the mitosis frequency and colonyformation ability in cultures treated for $24 \mathrm{~h}$. According to results, there was a significant reduction $(p<0.01)$ in mitosis frequency in treated cultures when compared to control group (Fig. 3B). Moreover, the ability of forming colony was significantly reduced by the compounds $\mathbf{1} / \mathbf{2}$ (Fig. 3C). We observed that colony frequency was $45 \%$ lower in samples treated at $20 \mu \mathrm{g} / \mathrm{mL}$ when compared to control cultures. In addition, no colonies were observed in samples treated at $40 \mu \mathrm{g} / \mathrm{mL}$ (Fig. 3D).

Considering the data obtained previously, we analyzed cell cycle progression after $24 \mathrm{~h}$ of treatment by flow cytometry (Fig. 3E) and observed a significant increase $(\mathrm{p}<0.05)$ in $\mathrm{G} 0 / \mathrm{G} 1$ population with concomitant decrease in S-phase populations in cultures treated with 
A.

MTS

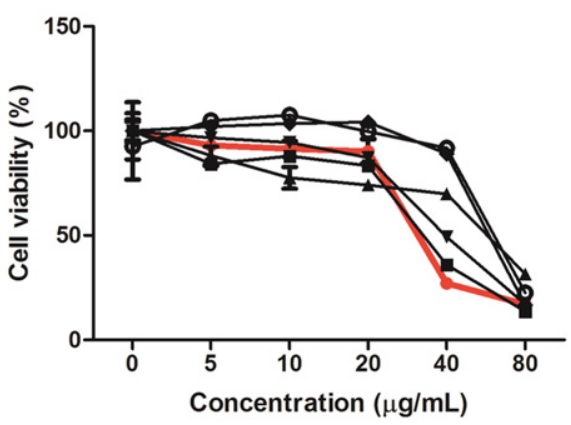

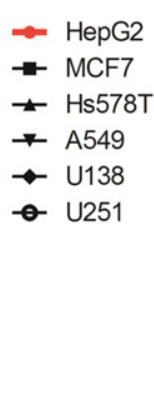

EXCLUSION ASSAY

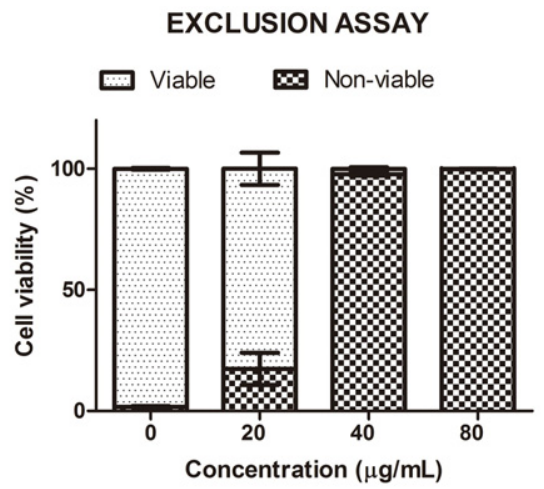

C.
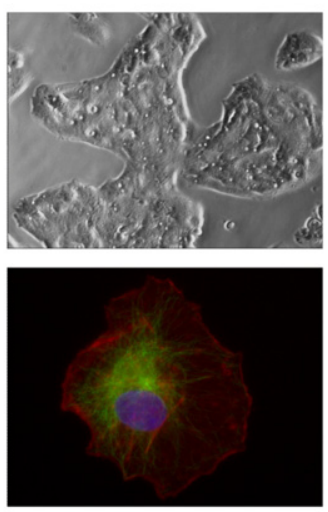

0
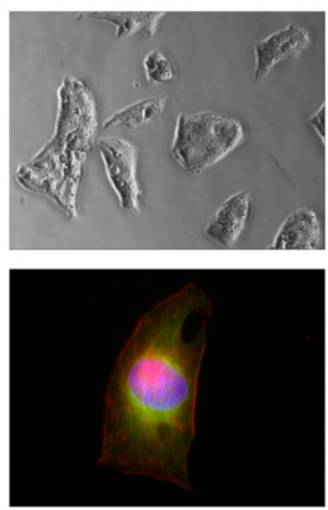

10
CELL MORPHOLOGY
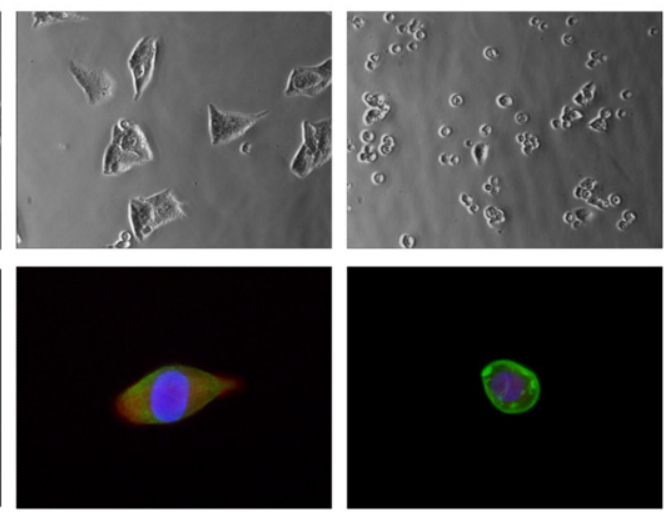

20

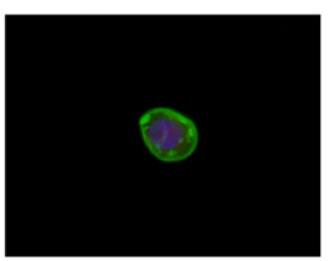

40

Concentration ( $\mu \mathrm{g} / \mathrm{mL}$ )

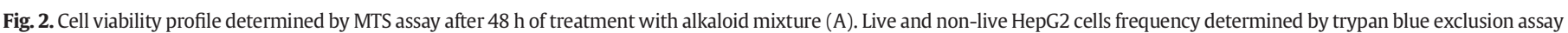

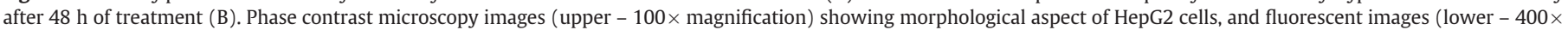

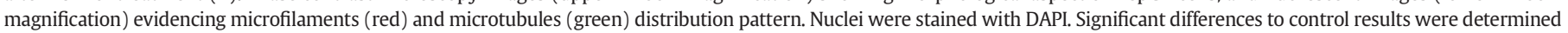
using ANOVA followed by Tukey's post-test from of 3 independent experiments. ${ }^{* * *} \mathrm{p}<0.001$ for samples treated at $20,40 \mathrm{or} 80 \mu \mathrm{g} / \mathrm{mL}$.

alkaloid mixture at $40 \mu \mathrm{g} / \mathrm{mL}$ (Fig. 3F). These findings demonstrate that the alkaloids inhibit cell cycle progression in G1/S transition. Following, we analyzed the mRNA expression for cyclin D1, whose levels are elevated during G1 progression. Alkaloids at $20 \mu \mathrm{g} / \mathrm{mL}$ were effective in inducing cyclin D1 mRNA down-regulation (Fig. 4A). So, we decided to investigate if the alkaloids could influence an upstream regulator of Cyclin D expression, the extracellular signal-regulated kinase (ERK), a member of mitogen-activated protein kinase family (MAPKs) (Yamamoto et al., 2006). According to immunoblot results (Fig. 4B), total ERK expression was not altered in consequence to alkaloid treatment; by the contrast, they effectively inhibited ERK activation, as evidenced by slight detection of p-ERK immureactive bands in treated samples (Fig. 4C).

We also performed immunoblot for phospho-Ser10-histone $\mathrm{H} 3$, a specific marker of mitosis, to confirm our previous data regarding mitosis frequency. As expected, there was down-regulation in p-histone H3 expression, especially in samples treated with alkaloids at $40 \mu \mathrm{g} / \mathrm{mL}$ (Fig. 4D).

Table 1

$\mathrm{IC}_{50}$ values $(\mu \mathrm{g} / \mathrm{mL})$ determined from MTS data.

\begin{tabular}{lrrl}
\hline & \multicolumn{1}{c}{ HepG2 } & CCD-1059Sk & Selectivity index \\
\hline Alkaloids 1/2 & $26.45 \pm 1.73$ & $55.62 \pm 1.69$ & 2.10 \\
Doxorubicin & $0.56 \pm 0.02$ & $0.96 \pm 0.01$ & 1.71 \\
\hline
\end{tabular}

\section{Discussion}

Compounds $\mathbf{1}$ and $\mathbf{2}$ are the two major alkaloidal constituents extracted from leaves, flowers and fruits of $S$. spectabilis. Previous study evidenced moderated cytotoxicity of $\mathbf{2}$ on non-tumor cell lines (CHO and VERO) (Bolzani et al., 1995), while Sriphong et al. (2003) have reported cytotoxic potential of $\mathbf{1}$ on cancer cell lines (KB and BC1). Up to date, no other studies, focusing the antitumor potential of these alkaloids or possible mechanisms of action involved with their antiproliferative or cytotoxic activity on tumor cells have been reported. In the present study, we demonstrated that alkaloids $\mathbf{1} / \mathbf{2}$ have an important antiproliferative activity on hepatocellular carcinoma cell line (HepG2) due to their ability in reducing ERK activation and cyclin D1 expression.

We could determinate that antiproliferative activity of the mixture of compounds $\mathbf{1} / \mathbf{2}$ is closely related to cell cycle arrest in G1/S transition and that, at least in part, this event was due to down-regulation of both ERK phosphorylation and cyclin D1 expression. Cell cycle progressions through G1 phase and G1/S transition are events highly regulated by a complex mechanism that involves kinase proteins activation including cyclin-dependent kinases (CDKs). CDK4 and CDK6 are mainly activated by the cyclin $\mathrm{D}$ interaction and regulate the G0-G1 transition as well as progression through early G1 phase. In order, cyclin E is upregulated and CDK2-cyclin E complex is activated to the progression through late G1 phase and G1/S transition (Malumbres and Carnero, 2003; 
A

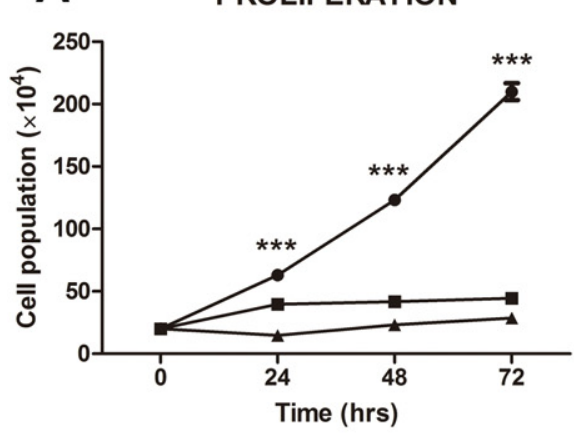

C.

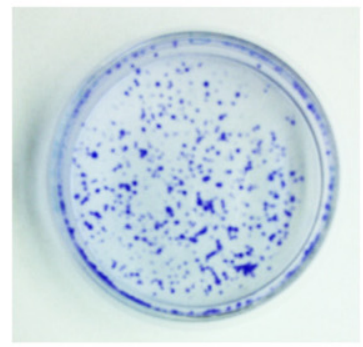

0
B

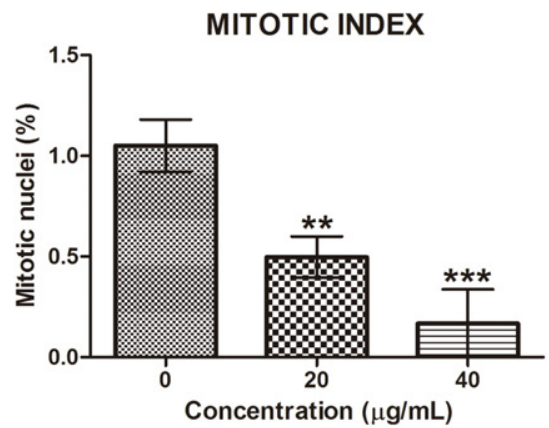

\section{CLONOGENIC CAPACITY}

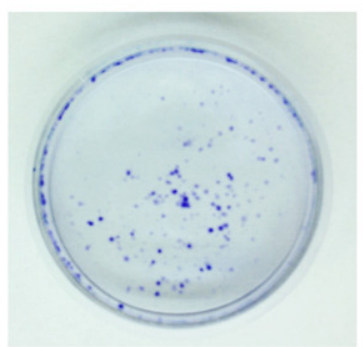

20

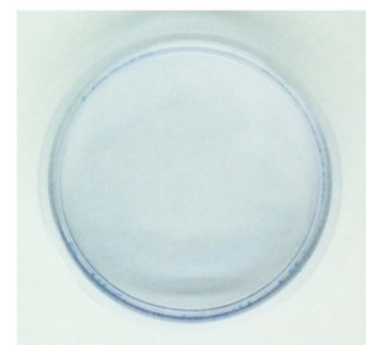

40

Concentration $(\mu \mathrm{g} / \mathrm{mL})$

D

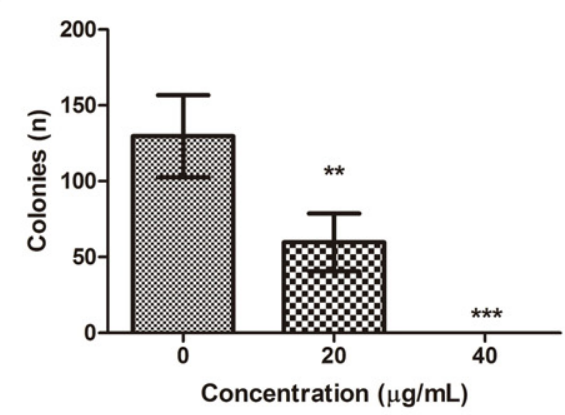

$\mathbf{F}$.
E.

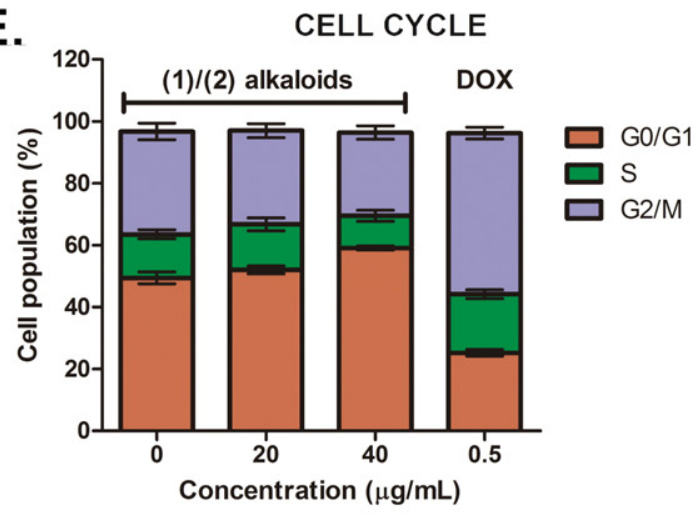

CELL CYCLE FLOW CYTOMETRY

Concentration $(\mu \mathrm{g} / \mathrm{mL})$

(1)/(2) alkaloids

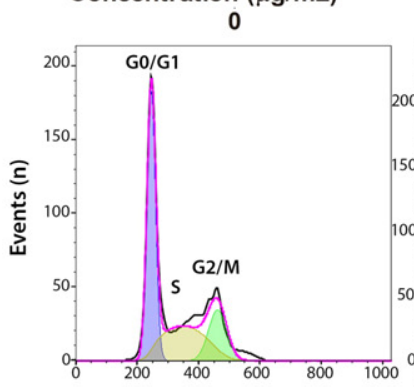

20
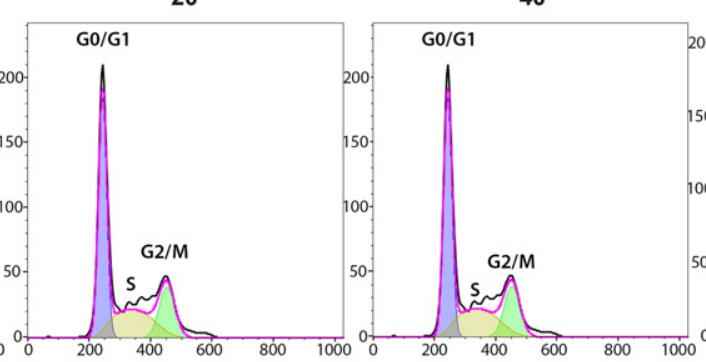

DOX

DNA Content (AU)

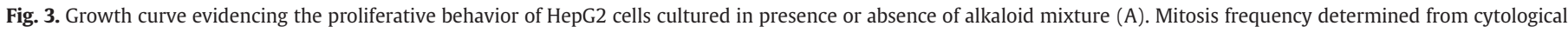

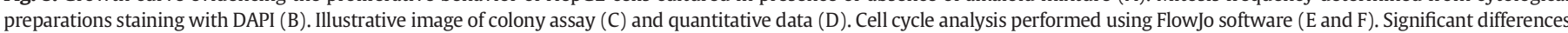
to control results were determined using ANOVA followed by Tukey's post-test from 3 independent experiments. ${ }^{* *} \mathrm{p}<0.01$ and ${ }^{* * *} \mathrm{p}<0.001$.

Malumbres and Barbacid, 2005). Considering that human cancers commonly show a deregulated control of G1 phase progression, chemical compounds that regulate the activity of these kinases are useful for cancer therapy.
It has been reported that cyclin D1 is overexpressed in HCC (Malumbres and Carnero, 2003; Zhu et al., 2003) and this event may be associated to altered mitogen-activated protein kinases (MAPKs) signaling pathway (Musgrove, 2006). The extracellular signal-regulated 

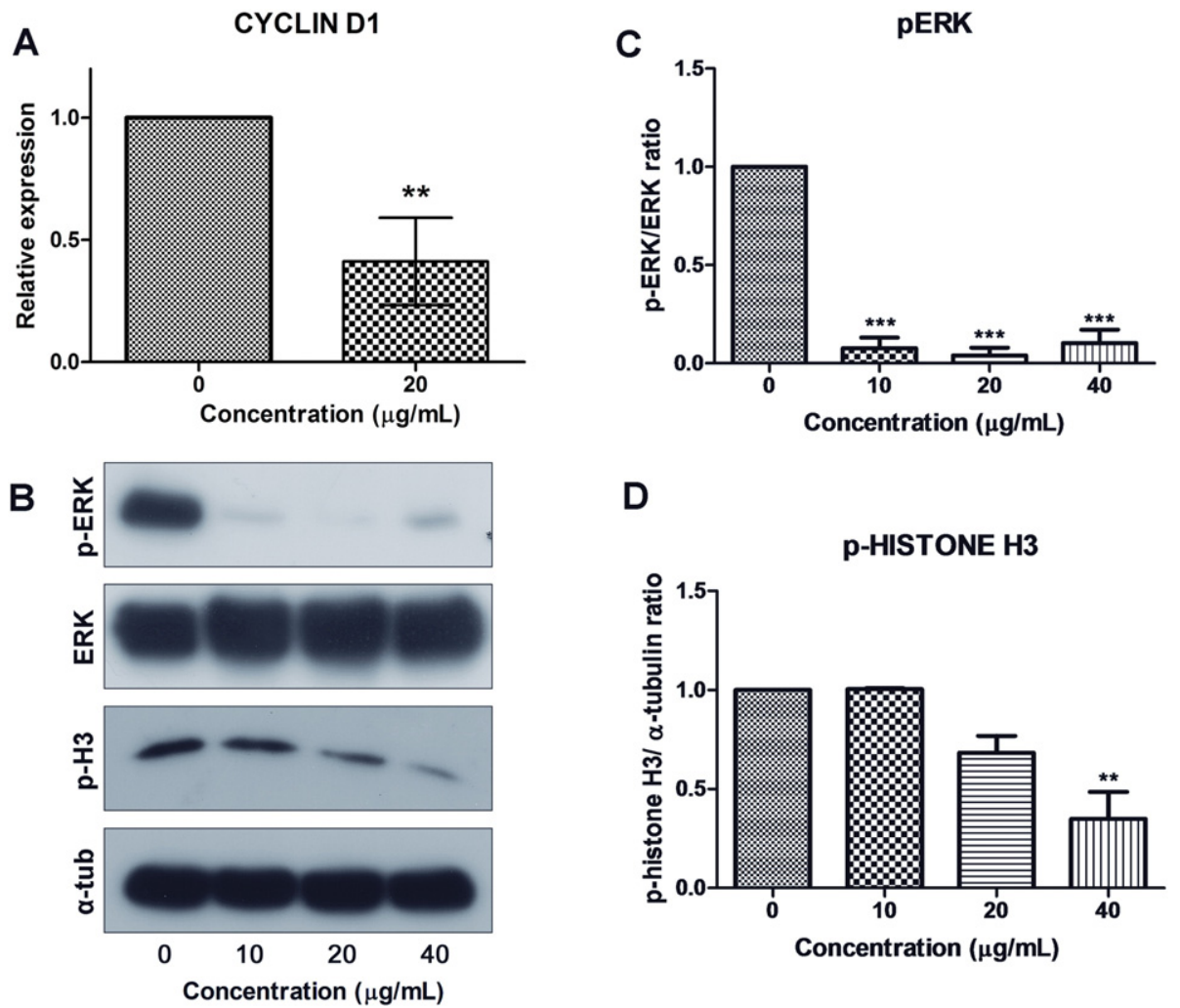

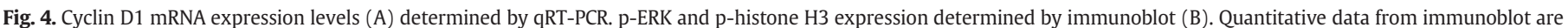

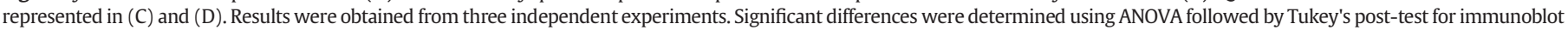
data, and Student's test for qRT-PCR results. ${ }^{* *} \mathrm{p}<0.01$ and ${ }^{* * *} \mathrm{p}<0.001$.

kinase (ERK) is a subfamily member of MAPKs that commonly is upregulated in HCC. Hwang et al. (2011) reported that RAF/MEK/ERK pathway can be activated during hepatocarcinogenesis due to major etiologic factors such as HBV and HCV infection and mitogenic growth factors. Therefore, looking for a best understanding of the molecular mechanism involved in cell cycle arrest in G1/S transition in HepG2 cells by the mixture of alkaloids $\mathbf{1 / 2}$, we investigated changes in the expression of cyclin D1 and phosphorylation levels of ERK.

According to our results, alkaloids effectively induced downregulation in cyclin D1 and inhibited ERK activation. Thus, we demonstrated by the first time that alkaloids $(-)$-cassine $(\mathbf{1}) /(-)$-spectaline (2) have an important role in modulating both Cyclin D expression and ERK phosphorylation. These biological events probably are associated to their ability of promoting cell cycle arrest in G1/S transition. Up to date, there have been no reports concerning this issue. It has been report that piperine, a piperidine alkaloid abundant in peppers, had similar effect on human fibrosarcoma HT-1080 cells, therefore effective reduced ERK phosphorylation (Hwang et al., 2011). In HCC, deregulated ERK signaling pathway has been associated to invasion capacity and metastasis beyond cell proliferation. Thus, our data are promise and open up the prospect of using these alkaloids as new chemical entities for liver cancer therapy.

The ability of cancer cells to form colonies is essential for the spread of a malignant tumor to distant organs (Eccles and Welch, 2007) and we demonstrated that alkaloids are effective in inhibiting in vitro this event. Considering still that ERK activation is crucial for invasion process (Min et al., 2011), we employed actin cytoskeleton analysis and verified that alkaloid treatment altered normal distribution pattern of actin filaments in HepG2 cells. A disorganization of microfilaments network due to the treatment was observed. F-actin is one type of stress fiber that regulates cell motility and polarization. In cancer, cells with a highly metastatic property, active polymerization of F-actin is often reported, and the reduction of the F-actin cytoskeleton could inhibit the migration of cancer cells (Havaki et al., 2007; Smerling et al., 2007). Further investigations should be performed for a better understanding of connection between the inhibition of ERK phosphorylation and actin cytoskeleton.

\section{Conclusion}

In conclusion, the natural mixture of the alkaloids $(-)$-cassine/( -$)$ spectaline had an important antiproliferative activity on HepG2 cells. We demonstrated by the first time that these alkaloids inhibited ERK activation and induced down-regulation of cyclin D1 in HepG2 cells. Our results disclose that the structural pattern of 2,3,6-trisubstituted piperidine alkaloids, such as $(-)$-cassine and $(-)$-spectaline, could be an innovative prototype of drug candidates in cancer therapy, especially for HCC.

\section{Conflicts of interest}

The authors declare no conflicts of interest.

\section{Transparency Document}

The Transparency document associated with this article can be found, in online version.

\section{Acknowledgments}

The authors are grateful to Brazilian Agencies CNPq (\#454088/20140, INCT-INOFAR \#573564/2008-6), FAPEMIG (\#CEX-PPM-00241-15, \#APQ-00341-13), CAPES, FAPESP and FINEP for financial support and fellowships. 


\section{References}

Agarkar, S.V., Jadge, D.R., 1999. Phytochemical and pharmacological investigations of genus Cassia: a review. Asian J. Chem. 11, 295-299.

Akah, P.A., Orisakwe, O.E., Gamaniel, K.S., Shittu, A., 1998. Evaluation of Nigerian traditional medicines: II. Effects of some Nigerian folk remedies on peptic ulcer. J. Ethnopharmacol. 62, 123-127.

Ayo, R.G., Amupitan, J.O., Zhao, Y., 2007. Cytotoxicity and antimicrobial studies of 1,6,8trihydroxy-3-methyl-anthraquinone (emodin) isolated from the leaves of Cassia nigricans Vahl. Afr. J. Biotechnol. 6, 1276-1279.

Bhakta, T., Mukherjee, P.K., Mukherjee, K., Benerjee, S., Mandal, S.C., Maity, T.K., Pal, M., Saha, B.P., 1999. Evaluation of hepatoprotective activity of Cassia fistula leaf extract. J. Ethnopharmacol. 66, 277-282.

Bolzani, V.S., Gunatilaka, A.A.L., Kingston, D.G.I., 1995. Bioactive and other piperidine alkaloids from Cassia leptophylla. Tetrahedron 51, 5929-5934.

Bruix, J., Raoul, J.L., Sherman, M., Mazzaferro, V., Bolondi, L., Craxi, A., Llovet, J.M., 2012. Efficacy and safety of sorafenib in patients with advanced hepatocellular carcinoma: subanalyses of a phase III trial. J. Hepatol. 57, 821-829.

Bum, E.N., Nkantchoua, G.N., Njikam, N., Taiwe, G.S., Ngoupaye, G.T., Pelanken, M.M., Nanga, Rakotonirina, A., Rakotonirina, S.V., 2010. Anticonvulsant and sedative activity of leaves of Senna spectabilis in mice. Int. J. Pharmacol. 6, 123-128.

Eccles, S.A., Welch, D.R., 2007. Metastasis: recent discoveries and novel treatment strategies. Lancet 369, 1742.

Franken, N.A., Rodermond, H.M., Stap, J., Haveman, J., van Bree, C., 2006. Clonogenic assay of cells in vitro. Nat. Protoc. 1 (5), 2315-2319.

Havaki, S., Kouloukoussa, M., Amawi, K., Drosos, Y., Arvanitis, L.D., Goutas, N., Vlachodimitropoulos, D., Vassilaros, S.D., Katsantoni, E.Z., Voloudakis-Baltatzis, I., Aleporou-Marinou, V., Kittas, C., Marinos, E., 2007. Altered expression pattern of integrin alphavbeta3 correlates with actin cytoskeleton in primary cultures of human breast cancer. Cancer Cell Int. 7 (16), 1-13.

Hwang, Y.P., Yun, H.J., Kim, H.G., Han, E.H., Choi, J.H., Chung, Y.C., Jeong, H.G., 2011. Suppression of phorbol-12-myristate-13-acetate-induced tumor cell invasion by piperine via the inhibition of PKC $\alpha$ /ERK1/2-dependent matrix metalloproteinase-9 expression. Toxicol. Lett. 203 (1), 9-19.

Ibrahim, D., Osman, H., 1995. Antimicrobial activity of Cassia alata from Malaysia. J. Ethnopharmacol. 45, 151-156.

Jafri, M.A., Subhani, M.J., Javed, K., Surender, S., 1999. Hepatoprotective activity of leaves of Cassia occidentalis against paracetamol and ethyl alcohol intoxication in rats. J. Ethnopharmacol. 66, 355-361.

Jain, S.C., Jain, R., Sharma, R.A., Capasso, F., 1997. Pharmacological investigation of Cassia italic. J. Ethnopharmacol. 58, 135-142.

Jothy, S.L., Torey, A., Darah, I., Choong, Y.S., Saravanan, D., Chen, Y., Latha, L.Y., Deivanai, S., Sasidharan, S., 2012. Cassia spectabilis (DC) Irwin et barn: a promising traditional herb in health improvement. Molecules 17, 10292-10305.

Livak, K.J., Schmittgen, T.D., 2001. Analysis of relative gene expression data using realtime quantitative PCR and the $2-\Delta \Delta C T$ method. Methods 25 (4), 402-408.

Lorenzi, H., 1998. Árvores Brasileiras: Manual de Identificação e Cultivo de Plantas Arbóreas do Brasil. 2nd ed. Plantarum, Nova Odessa, pp. 151-167.

Malumbres, M., Barbacid, M., 2005. Mammalian cyclin-dependent kinases. Trends Biochem. Sci. 30 (11), 630-641.

Malumbres, M., Carnero, A., 2003. Cell cycle deregulation: a common motif in cancer. Prog. Cell Cycle Res. 5, 5-18.
Mascolo, N., Capasso, R., Capasso, F., 1998. Senna. A safe and effective drug. Phytother. Res. 12, S143-S145.

Min, L., He, B., Hui, L., 2011. Mitogen-activated protein kinases in hepatocellular carcinoma development. Semin. Cancer Biol. 21 (1), 10-20.

Musgrove, E.A., 2006. Cyclins: roles in mitogenic signaling and oncogenic transformation. Growth Factors 24, 13-19.

Nsonde-Ntandou, G.F., Ndounga, M., Ouamba, J.M., Gbeassor, M., Etou-Ossebi, A., Ntoumi, F., Abena, A.A., 2005. Enquête ethnobotanique: screening chimique et efficacité thérapeutique de quelques plantes utilisées contre le paludisme en médecine traditionnelle à Brazzaville. Phytothérapie 3, 13-18.

Pivatto, M., Crotti, A.E.M., Lopes, N.P., Castro-Gamboa, I., Rezende, A., Viegas Jr., C., Young M.C.M., Furlan, M., Bolzani, V., 2005. Electrospray ionization mass spectrometry screening of piperidine alkaloids from Senna spectabilis (Fabaceae) extracts: fast identification of new constituents and co-metabolites. J. Braz. Chem. Soc. 16 (6b), 1431-1438.

Samy, R.P., Ignacimuthu, S., 2000. Antibacterial activity of some folklore medicinal plants used by tribals in Western Ghats of India. J. Ethnopharmacol. 69, 63-71.

Samy, R.P., Ignacimuthu, S., Sen, A., 1998. Screening of 34 Indian medicinal plants for antibacterial properties. J. Ethnopharmacol. 62, 173-182.

Silva, F.O., Oliveira, I.R., Silva, M.G.V., Braz-Filho, R., 2010. Constituintes químicos das folhas de Senna spectabilis (DC) IRWIN \& BARNEBY var. Excelsa (Schrad.) IRWIN \& BARNEBY. Quim Nova 33, 1874-1876.

Smerling, C., Tang, K., Hofmann, W., Danker, K., 2007. Role of the alpha(1) integrin cytoplasmic tail in the formation of focal complexes, actin organization, and in the control of cell migration. Exp. Cell Res. 313 (14), 3153-3165.

Sriphong, L., Sotanaphun, U., Limsirichaikul, S., Wetwitayaklung, P., Chaichantipyuth, C. Pummangura, S., 2003. Cytotoxic alkaloids from the flowers of Senna spectabilis. Planta Med. 69, 1054-1056.

Tona, L. Ngimbi, N.P., Tsakala, M. Cimanga, M.K. Apers, S, De Bruyne, T., Pieters, L., Totté, J., Vlietinck, A.J., 1999. Antimalarial activity of 20 crude extracts from nine African medicinal plants used in Kinshasa, Congo. J. Ethnopharmacol. 68, 193-203.

Torre, L.A., Bray, F., Siegel, R.L., Ferlay, J., Lortet-Tieulent, J., Jemal, A., 2012. Global cancer statistics, 2012. CA Cancer J. Clin. 65, 87-108.

Veerachari, U., Bopaiah, A.K., 2011. Preliminary phytochemical evaluation of the leaf extract of five Cassia species. J. Chem. Pharm. Res. 3 (5), 574-583.

Viegas Jr., C., Bolzani, V.C., Furlan, M., Barreiro, E.J., Young, M.C.M., Tomazela, D., Eberlin, M.N., 2004. Further bioactive piperidine alkaloids from the flowers and green fruits of Cassia spectabilis. J. Nat. Prod. 67, 908-910.

Viegas Jr., C., Rezende, A., Silva, D.H.S., Castro-Gambôa, I., Bolzani, V.S., Barreiro, E.J. Miranda, A.L.P., Alexandre-Moreira, M.S., Young, M.C.M., 2006. Aspectos químicos e etnofarmacológicos do gênero Cassia. Quim. Nova 29, 1279-1286.

Viegas Jr., C., Pivatto, M., de Rezende, A., Hamerski, A., Silva, D.H.S., Bolzani, V.S., 2013. (-)-7-hydroxycassine: a new 2,6-dialkylpiperidin-3-ol alkaloid and other constituents isolated from flowers and fruits of Senna spectabilis (Fabaceae). J. Braz. Chem. Soc. 24 (2), 230-235

Yamamoto, T., Ebisuya, M., Ashida, F., Okamoto, K., Yonehara, S., Nishida, E., 2006. Continuous ERK activation downregulates antiproliferative genes throughout G1 phase to allow cell-cycle progression. Curr. Biol. 16 (12), 1171-1182.

Zhu, M.H., Ni, C.R., Zhu, Z., Li, F.M., Zhang, S.M., 2003. Immunohistochemical demonstration of cyclins a,B,D1,D3 and $\mathrm{E}$ in hepatocellular carcinomas using tissue microarrays. Zhonghua Bing Li Xue Za Zhi; 32 (5), 440-443. 